4

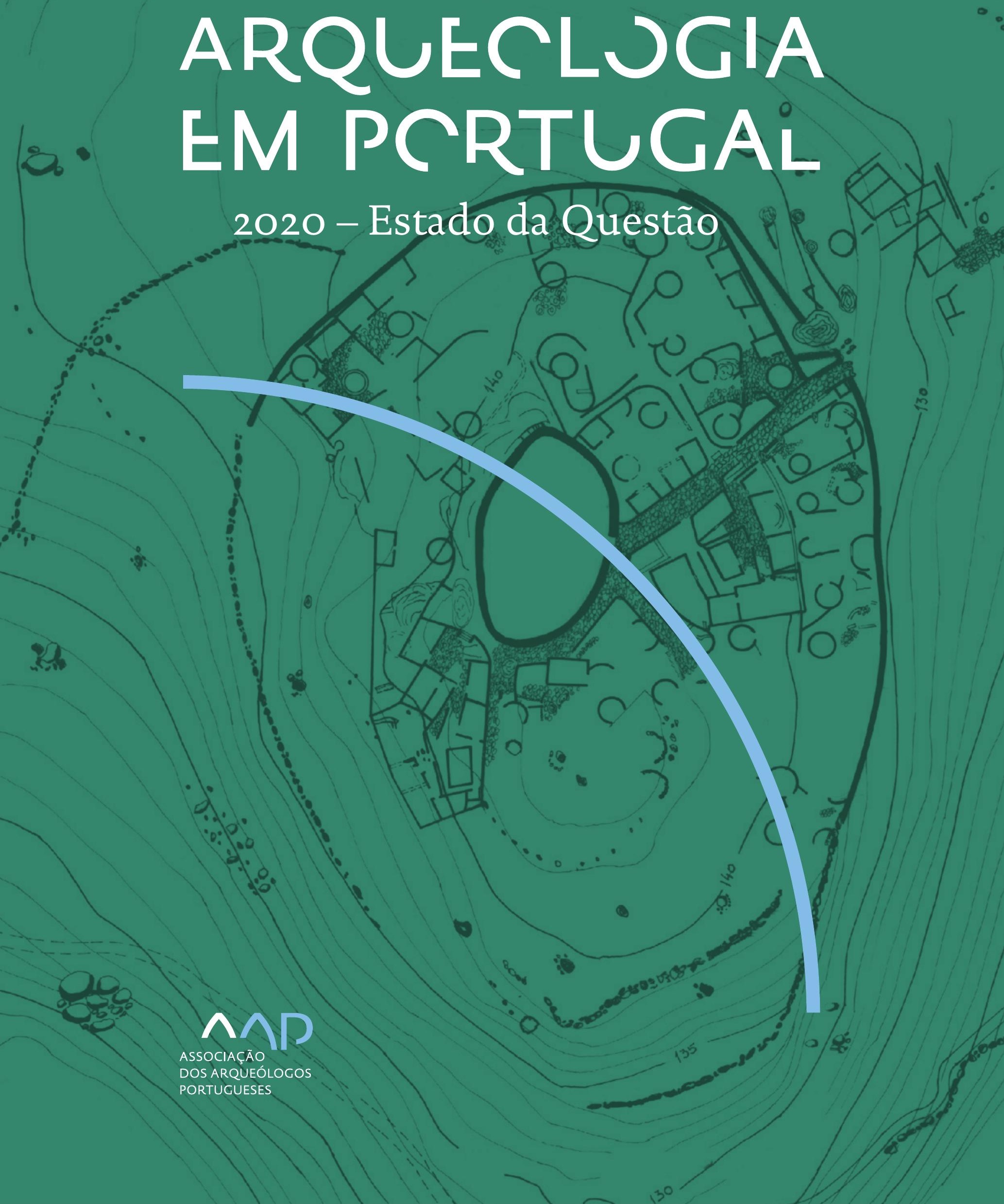


Coordenação editorial: José Morais Arnaud, César Neves e Andrea Martins Design gráfico: Flatland Design

AAP - ISBN: 978-972-9451-89-8

CITCEM - ISBN: 978-989-8970-25-1

Associação dos Arqueólogos Portugueses e CITCEM

Lisboa, 2020

O conteúdo dos artigos é da inteira responsabilidade dos autores. Sendo assim a Associação dos Arqueólogos Portugueses declina qualquer responsabilidade por eventuais equívocos ou questões de ordem ética e legal.

Desenho de capa:

Planta do castro de Monte Mozinho (Museu Municipal de Penafiel).

\section{$\hat{\wedge} \mathrm{P}$}

DOS ARQUEÓLOGOS PORTUGUESES

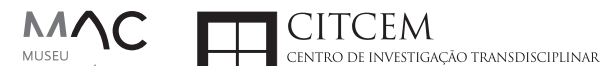
MUSEU
ARQUELLÓGICO
DO CARMO
U.PORTO

FLUP FACULDADE DE LETRAS
UNIVERSIDADE DO PORTO

Apoio

EC para a Ciência 


\section{Índice}

15 Prefácio

José Morais Arnaud

\section{Historiografia e Teoria}

17 Território, comunidade, memória e emoção: a contribuição da história da arqueologia (algumas primeiras e breves reflexões)

Ana Cristina Martins

25 Como descolonizar a arqueologia portuguesa?

Rui Gomes Coelho

41 Arqueologia e Modernidade: uma revisitação pessoal e breve de alguns aspetos da obra homónima de Julian Thomas de 2004

Vítor Oliveira Jorge

57 Dados para a História das Mulheres na Arqueologia portuguesa, dos finais do século XIX aos inícios do século XX: números, nomes e tabelas

Filipa Dimas / Mariana Diniz

73 Retractos da arqueologia portuguesa na imprensa: (in)visibilidades no feminino

Catarina Costeira / Elsa Luís

85 Arqueologia e Arqueólogos no Norte de Portugal Jacinta Bugalhão

101 Vieira Guimarães (1864-1939) e a arqueologia em Tomar: uma abordagem sobre o território e as gentes

João Amendoeira Peixoto / Ana Cristina Martins

115 Os memoráveis? A arqueologia algarvia na imprensa nacional e regional na presente centúria (2001-2019): características, visões do(s) passado(s) e a arqueologia

enquanto marca

Frederico Agosto / João Silva

129 A Evolução da Arqueologia Urbana e a Valorização Patrimonial no Barlavento Algarvio: Os casos de Portimão e Silves

Artur Mateus / Diogo Varandas / Rafael Boavida

\section{Gestão, Valorização e Salvaguarda do Património}

145 O Caderno Reivindicativo e as condições de trabalho em Arqueologia Miguel Rocha / Liliana Matias Carvalho / Regis Barbosa / Mauro Correia / Sara Simões / Jacinta Bugalhão / Sara Brito / Liliana Veríssimo Carvalho / Richard Peace / Pedro Peça / Cézer Santos

155 Os Estudos de Impacte Patrimonial como elemento para uma estratégia sustentável de minimização de impactes no âmbito de reconversões agrícolas Tiago do Pereiro

165 Salvaguarda de Património arqueológico em operações florestais: gestão e sensibilização Filipa Bragança / Gertrudes Zambujo / Sandra Lourenço / Belém Paiva / Carlos Banha / Frederico Tatá Regala / Helena Moura / Jacinta Bugalhão / João Marques / José Correia / Pedro Faria / Samuel Melro

179 Os valores do Património: uma investigação sobre os Sítios Pré-históricos de Arte Rupestre do Vale do Rio Côa e de Siega Verde José Paulo Francisco 
189 Conjugando recursos arqueológicos e naturais para potenciar as visitas ao Geoparque Litoral de Viana do Castelo (Noroeste de Portugal)

Hugo A. Sampaio / Ana M.S. Bettencourt / Susana Marinho / Ricardo Carvalhido

203 Áreas de Potencial Arqueológico na Região do Médio Tejo: Modelo Espacial Preditivo Rita Ferreira Anastácio / Ana Filipa Martins / Luiz Oosterbeek

223 Património Arqueológico e Gestão Territorial: O contributo da Arqueologia para a revisão do PDM de Avis

Ana Cristina Ribeiro

237 A coleção arqueológica do extinto Museu Municipal do Porto - Origens, Percursos e Estudos

Sónia Couto

251 Valpaços - uma nova carta arqueológica

Pedro Pereira / Maria de Fátima Casares Machado

263 Arqueologia na Cidade de Peniche

Adriano Constantino / Luís Rendeiro

273 Arqueologia Urbana: a cidade de Lagos como caso de Estudo Cátia Neto

285 Estratégias de promoção do património cultural subaquático nos Açores. O caso da ilha do Faial

José Luís Neto / José Bettencourt / Luís Borges / Pedro Parreira

297 Carta Arqueológica da Cidade Velha: Uma primeira abordagem

Jaylson Monteiro / Nireide Tavares / Sara da Veiga / Claudino Ramos / Edson Brito /

Carlos Carvalho / Francisco Moreira / Adalberto Tavares

311 Antropologia Virtual: novas metodologias para a análise morfológica e funcional Ricardo Miguel Godinho / Célia Gonçalves

\section{Didáctica da Arqueologia}

327 Como os projetos de Arqueologia podem contribuir para uma comunidade culturalmente mais consciente Alexandra Figueiredo / Claúdio Monteiro / Adolfo Silveira / Ricardo Lopes

337 Educação Patrimonial - Um cidadão esclarecido é um cidadão ativo! Ana Paula Almeida

351 A aproximação da Arqueologia à sala de aula: um caso de estudo no $3^{\circ}$ ciclo do Ensino Básico Luís Serrão Gil

363 Arqueologia 3.o - Pensar e comunicar a Arqueologia para um futuro sustentável Mónica Rolo

377 “Conversa de Arqueólogos" - Divulgar a Arqueologia em tempos de Pandemia Diogo Teixeira Dias

389 Escola Profissional de Arqueologia: desafios e oportunidades Susana Nunes / Dulcineia Pinto / Júlia Silva / Ana Mascarenhas

399 Os Museus de Arqueologia e os Jovens: a oferta educativa para o público adolescente Beatriz Correia Barata / Leonor Medeiros

411 O museu universitário como mediador entre a ciência e a sociedade: o exemplo da secção de arqueologia no Museu de História Natural e da Ciência da Universidade do Porto (MHNC-UP)

Rita Gaspar 
421 Museu de Lanifícios: Real Fábrica de Panos. Atividades no âmbito da Arqueologia Beatriz Correia Barata / Rita Salvado

427 Arqueologia Pública e o caso da localidade da Mata (Torres Novas) Cláudia Manso / Ana Rita Ferreira / Cristiana Ferreira / Vanessa Cardoso Antunes

431 Do sítio arqueológico ao museu: um percurso (também) didático Lídia Fernandes

447 Estão todos convidados para a Festa! E para dançar também... O projecto do Serviço Educativo do Museu Arqueológico do Carmo na $5^{\underline{a}}$ Edição da Festa da Arqueologia Rita Pires dos Santos

459 O “Clã de Carenque”, um projeto didático de arqueologia Eduardo Gonzalez Rocha

469 Mediação cultural: peixe que puxa carroça nas Ruínas Romanas de Troia Inês Vaz Pinto / Ana Patrícia Magalhães / Patrícia Brum / Filipa Santos

481 Didática Arqueológica, experiências do Projeto Mértola Vila Museu Maria de Fátima Palma / Clara Rodrigues / Susana Gómez / Lígia Rafael

\section{Arte Rupestre}

497 Os inventários de arte rupestre em Portugal Mila Simões de Abreu

513 O projeto FIRST-ART - conservação, documentação e gestão das primeiras manifestações de arte rupestre no Sudoeste da Península Ibérica: as grutas do Escoural e Maltravieso Sara Garcês / Hipólito Collado / José Julio García Arranz / Luiz Oosterbeek / António Carlos Silva / Pierluigi Rosina / Hugo Gomes / Anabela Borralheiro Pereira / George Nash / Esmeralda Gomes / Nelson Almeida / Carlos Carpetudo

523 Trabalhos de documentação de arte paleolítica realizados no âmbito do projeto PalæoCôa André Tomás Santos / António Fernando Barbosa / Luís Luís / Marcelo Silvestre / Thierry Aubry

537 Imagens fantasmagóricas, silhuetas elusivas: as figuras humanas na arte do Paleolítico Superior da região do Côa Mário Reis

$55^{1}$ Os motivos zoomórficos representados nas placas de tear de Vila Nova de São Pedro (Azambuja, Portugal) Andrea Martins / César Neves / José M. Arnaud / Mariana Diniz

571 Arte Rupestre do Monte de Góios (Lanhelas, Caminha). Síntese dos resultados dos trabalhos efectuados em 2007-2009 Mário Varela Gomes

599 Gravuras rupestres de barquiformes no Monte de S. Romão, Guimarães, Noroeste de Portugal Daniela Cardoso

613 Círculos segmentados gravados na Bacia do Rio Lima (Noroeste de Portugal): contributos para o seu estudo Diogo Marinho / Ana M.S. Bettencourt / Hugo Aluai Sampaio

631 Equídeos gravados no curso inferior do Rio Mouro, Monção (NW Portugal). Análise preliminar Coutinho, L.M. / Bettencourt, A.M.S / Sampaio, Hugo A.S

645 Paletas na Arte Rupestre do Noroeste de Portugal. Inventário preliminar Bruna Sousa Afonso / Ana M. S. Bettencourt / Hugo A. Sampaio 


\section{Pré-História}

661 O projeto Miño/Minho: balanço de quatro anos de trabalhos arqueológicos Sérgio Monteiro-Rodrigues / João Pedro Cunha-Ribeiro / Eduardo Méndez-Quintas / Carlos Ferreira / Pedro Xavier / José Meireles / Alberto Gomes / Manuel Santonja / Alfredo Pérez-González

677 A ocupação paleolítica da margem esquerda do Baixo Minho: a indústria lítica do sítio de Pedreiras 2 (Monção, Portugal) e a sua integração no contexto regional Carlos Ferreira / João Pedro Cunha-Ribeiro / Sérgio Monteiro-Rodrigues / Eduardo Méndez-Quintas / Pedro Xavier / José Meireles / Alberto Gomes / Manuel Santonja / Alfredo Pérez-González

693 O sítio acheulense do Plistocénico médio da Gruta da Aroeira Joan Daura / Montserrat Sanz / Filipa Rodrigues / Pedro Souto / João Zilhão

703 As sociedades neandertais no Barlavento algarvio: modelos preditivos com recurso aos SIG

Daniela Maio

715 A utilização de quartzo durante o Paleolítico Superior no território dos vales dos rios Vouga e Côa

Cristina Gameiro / Thierry Aubry / Bárbara Costa / Sérgio Gomes / Luís Luís / Carmen Manzano / André Tomás Santos

733 Uma perspetiva diacrónica da ocupação do concheiro do Cabeço da Amoreira (Muge, Portugal) a partir da tecnologia lítica Joana Belmiro / João Cascalheira / Célia Gonçalves

745 Novos dados sobre a Pré-história Antiga no concelho de Palmela. A intervenção arqueológica no sítio do Poceirão I

Michelle Teixeira Santos

757 Problemas em torno de Datas Absolutas Pré-Históricas no Norte do Alentejo Jorge de Oliveira

771 Povoamento pré-histórico nas áreas montanhosas do NO de Portugal: o Abrigo 1 de Vale de Cerdeira Pedro Xavier / José Meireles / Carlos Alves

783 Apreciação do povoamento do Neolítico Inicial na Baixa Bacia do Douro. A Lavra I (Serra da Aboboreira) como caso de estudo Maria de Jesus Sanches

797 O Processo de Neolitização na Plataforma do Mondego: os dados do Sector C do Outeiro dos Castelos de Beijós (Carregal do Sal)

João Carlos de Senna-Martinez / José Manuel Quintã Ventura / Andreia Carvalho / Cíntia Maurício

823 Novos trabalhos na Lapa da Bugalheira (Almonda, Torres Novas) Filipa Rodrigues / Pedro Souto / Artur Ferreira / Alexandre Varanda / Luís Gomes / Helena Gomes / João Zilhão

837 A pedra polida e afeiçoada do sítio do Neolítico médio da Moita do Ourives (Benavente, Portugal)

César Neves

857 Casal do Outeiro (Encarnação, Mafra): novos contributos para o conhecimento do povoamento do Neolítico final na Península de Lisboa.

Cátia Delicado / Carlos Maneira e Costa / Marta Miranda / Ana Catarina Sousa

873 Stresse infantil, morbilidade e mortalidade no sítio arqueológico do Neolítico Final/ Calcolítico ( $4^{\circ}$ e $3^{\circ}$ milénio a.C.) do Monte do Carrascal 2 (Ferreira do Alentejo, Beja) Liliana Matias de Carvalho / Sofia N. Wasterlain 
885 Come together: O Conjunto Megalítico das Motas (Monção, Viana do Castelo) e as expressões Campaniformes do Alto Minho Ana Catarina Basílio / Rui Ramos

899 Trabalhos arqueológicos no sítio Calcolítico da Pedreira do Poio Carla Magalhães / João Muralha / Mário Reis / António Batarda Fernandes

913 O sítio arqueológico de Castanheiro do Vento. Da arquitectura do sítio à arquitectura de um território João Muralha Cardoso

925 Estudo zooarqueológico das faunas do Calcolítico final de Vila Nova de São Pedro (Azambuja, Portugal): Campanhas de 2017 e 2018 Cleia Detry / Ana Catarina Francisco / Mariana Diniz / Andrea Martins / César Neves / José Morais Arnaud

943 As faunas depositadas no Museu Arqueológico do Carmo provenientes de Vila Nova de São Pedro (Azambuja): as campanhas de 1937 a 1967 Ana Catarina Francisco / Cleia Detry / César Neves / Andrea Martins / Mariana Diniz / José Morais Arnaud

959 Análise funcional de material lítico em sílex do castro de Vila Nova de S. Pedro (Azambuja, Portugal): uma primeira abordagem Rafael Lima

971 O recinto da Folha do Ouro 1 (Serpa) no contexto dos recintos de fossos calcolíticos alentejanos

António Carlos Valera / Tiago do Pereiro / Pedro Valério / António M. Monge Soares

\section{Proto-História}

987 Produção de sal marinho na Idade do Bronze do noroeste Português. Alguns dados para uma reflexão

Ana M. S. Bettencourt / Sara Luz / Nuno Oliveira / Pedro P. Simões / Maria Isabel C. Alves / Emílio Abad-Vidal

1001 A estátua-menir do Pedrão ou de São Bartolomeu do Mar (Esposende, noroeste de Portugal) no contexto arqueológico da fachada costeira de entre os rios Neiva e Cávado Ana M. S. Bettencourt / Manuel Santos-Estévez / Pedro Pimenta Simões / Luís Gonçalves

1015 O Castro do Muro (Vandoma/Baltar, Paredes) - notas para uma biografia de ocupação da Idade do Bronze à Idade Média

Maria Antónia D. Silva / Ana M. S. Bettencourt / António Manuel S. P. Silva / Natália Félix

1031 Do Bronze Final à Idade Média - continuidades e hiatos na ocupação de Povoados em Oliveira de Azeméis João Tiago Tavares / Adriaan de Man

1041 As faunas do final da Idade do Bronze no Sul de Portugal: leituras desde o Outeiro do Circo (Beja)

Nelson J. Almeida / Íris Dias / Cleia Detry / Eduardo Porfírio / Miguel Serra

1055 A Espada do Monte das Oliveiras (Serpa) - uma arma do Bronze Pleno do Sudoeste Rui M. G. Monge Soares / Pedro Valério / Mariana Nabais / António M. Monge Soares

1065 São Julião da Branca (Albergaria-a-Velha) - Investigação e valorização de um povoado do Bronze Final

António Manuel S. P. Silva / Paulo A. P. Lemos / Sara Almeida e Silva / Edite Martins de Sá

1083 Do castro de S. João ao Mosteiro de Santa Clara: notícia de uma intervenção arqueológica, em Vila do Conde Rui Pinheiro 
1095 O castro de Ovil (Espinho), um quarto de século de investigação - resultados e questões em aberto

Jorge Fernando Salvador / António Manuel S. P. Silva

1111 O Castro de Salreu (Estarreja), um povoado proto-histórico no litoral do Entre Douro e Vouga

Sara Almeida e Silva / António Manuel S. P. Silva / Paulo A. P. Lemos / Edite Martins de Sá

1127 Castro de Nossa Senhora das Necessidades (Sernancelhe): uma primeira análise artefactual Telma Susana O. Ribeiro

${ }_{1141}$ A cividade de Bagunte. O estado atual da investigação Pedro Brochado de Almeida

1153 Zoomorfos na cerâmica da Idade do Ferro no NW Peninsular: inventário, cronologias e significado Nuno Oliveira / Cristina Seoane

1163 Vasos gregos em Portugal: diferentes maneiras de contar a história do intercâmbio cultural na Idade do Ferro

Daniela Ferreira

1175 Os exotica da necrópole da Idade do Ferro do Olival do Senhor dos Mártires (Alcácer do Sal) no seu contexto regional

Francisco B. Gomes

\section{Antiguidade Clássica e Tardia}

1191 O uso de madeira como combustível no sítio da Quinta de Crestelos (Baixo Sabor): da Idade do Ferro à Romanização Filipe Vaz / João Tereso / Sérgio Simões Pereira / José Sastre / Javier Larrazabal Galarza / Susana Cosme / José António Pereira / Israel Espi

1207 Cultivos de Época Romana no Baixo Sabor: continuidade em tempos de mudança? João Pedro Tereso / Sérgio Simões Pereira / Filipe Santos / Luís Seabra / Filipe Vaz

1221 A casa romana na Hispânia: aplicação dos modelos itálicos nas províncias ibéricas Fernanda Magalhães / Diego Machado / Manuela Martins

1235 As pinturas murais romanas da Rua General Sousa Machado, n. ${ }^{5}$ 1, Chaves José Carvalho

1243 Trás do Castelo (Vale de Mir, Pegarinhos, Alijó) - Uma exploração agrícola romana do Douro

Tony Silvino / Pedro Pereira

1255 A sequência de ocupação no quadrante sudeste de Bracara Augusta: as transformações de uma unidade doméstica Lara Fernandes / Manuela Martins

1263 Os Mosaicos com decoração geométrica e geométrico-vegetalista dos sítios arqueológicos da área do Conuentus Bracaraugustanus. Novas abordagens quanto à conservação, restauro, decoração e datação Maria de Fátima Abraços / Licínia Wrench

1277 “Casa Romana” do Castro de São Domingos (Cristelos, Lousada): Escavação, Estudo e Musealização Paulo André de P. Lemos

1291 A arqueobotânica no Castro de Guifões (Matosinhos, Noroeste de Portugal): O primeiro estudo carpológico

Luís Seabra / Andreia Arezes / Catarina Magalhães / José Varela / João Pedro Tereso 
1305 Um Horreum Augustano na Foz do Douro (Monte do Castelo de Gaia, Vila Nova de Gaia) Rui Ramos

1311 Ponderais romanos na Lusitânia: padrões, formas, materiais e contextos de utilização Diego Barrios Rodríguez

1323 Um almofariz centro-itálico na foz do Mondego

Marco Penajoia

1335 Estruturas romanas de Carnide - Lisboa Luísa Batalha / Mário Monteiro / Guilherme Cardoso

1347 O contexto funerário do sector da "necrópole NO" da Rua das Portas de S. Antão (Lisboa): o espaço, os artefactos, os indivíduos e a sua interconectividade na interpretação do passado Sílvia Loja, José Carlos Quaresma, Nelson Cabaço, Marina Lourenço, Sílvia Casimiro, Rodrigo Banha da Silva, Francisca Alves-Cardoso

${ }_{1361}$ Povoamento em época Romana na Amadora - resultados de um projeto pluridisciplinar Gisela Encarnação / Vanessa Dias

1371 A Arquitectura Residencial em Mirobriga (Santiago do Cacém): contributo a partir de um estudo de caso Filipe Sousa / Catarina Felício

${ }_{1385}$ O fim do ciclo. Saneamento e gestão de resíduos nos edifícios termais de Mirobriga (Santiago do Cacém)

Catarina Felício / Filipe Sousa

1399 Balsa, Topografia e Urbanismo de uma Cidade Portuária Vítor Silva Dias / João Pedro Bernardes / Celso Candeias / Cristina Tété Garcia

1413 No Largo das Mouras Velhas em Faro (2017): novas evidências da necrópole norte de Ossonoba e da sua ocupação medieval Ricardo Costeira da Silva / Paulo Botelho / Fernando Santos / Liliana Nunes

1429 Instrumentos de pesca recuperados numa fábrica de salga em Ossonoba (Faro) Inês Rasteiro / Ricardo Costeira da Silva / Paulo Botelho

1439 A Necrópole Romana do Eirô, Duas Igrejas (Penafiel): intervenção arqueológica de 2016 Laura Sousa / Teresa Soeiro

1457 Ritual, descarte ou afetividade? A presença de Canis lupus familiaris na Necrópole Noroeste de Olisipo (Lisboa)

Beatriz Calapez Santos / Sofia Simões Pereira / Rodrigo Banha da Silva / Sílvia Casimiro / Cleia Detry / Francisca Alves Cardoso

1467 Dinâmicas económicas em Bracara na Antiguidade Tardia Diego Machado / Manuela Martins / Fernanda Magalhães / Natália Botica

1479 Cerâmicas e Vidros da Antiguidade Tardia do Edifício sob a Igreja do Bom Jesus (Vila Nova de Gaia) Joaquim Filipe Ramos

1493 Novos contributos para a topografia histórica de Mértola no período romano e na Antiguidade Tardia Virgílio Lopes

\section{8. Época Medieval}

1511 Cerâmicas islâmicas no Garb setentrional "português": algumas evidências e incógnitas Constança dos Santos / Helena Catarino / Susana Gómez / Maria José Gonçalves / Isabel Inácio / Gonçalo Lopes / Jacinta Bugalhão / Sandra Cavaco / Jaquelina Covaneiro / Isabel Cristina Fernandes / Ana Sofia Gomes 
1525 Contributo para o conhecimento da cosmética islâmica, em Silves, durante a Idade Média Rosa Varela Gomes

1537 Yábura e o seu território - uma análise histórico-arqueológica de Évora entre os séculos VIII-XII José Rui Santos

1547 A encosta sul do Castelo de Palmela - resultados preliminares da escavação arqueológica Luís Filipe Pereira / Michelle Teixeira Santos

1559 A igreja de São Lourenço (Mouraria, Lisboa): um conjunto de silos e de cerâmica medieval islâmica

Andreia Filipa Moreira Rodrigues

1571 O registo material de movimentações populacionais no Médio Tejo, durante os séculos XII-XIII. Dois casos de "sunken featured buildings", nos concelhos de Cartaxo e Torres Novas Marco Liberato / Helena Santos / Nuno Santos

1585 O nordeste transmontano nos alvores da Idade média. Notas para reflexão Ana Maria da Costa Oliveira

1601 Sepulturas escavadas na rocha do Norte de Portugal e do Vale do Douro: primeiros resultados do Projecto SER-NPVD

Mário Jorge Barroca / César Guedes / Andreia Arezes / Ana Maria Oliveira

1619 "Portucalem Castrum Novum" entre o Mediterrâneo e o Atlântico: o estudo dos materiais cerâmicos alto-medievais do arqueossítio da rua de D. Hugo, nํ. 5 (Porto) João Luís Veloso

1627 A Alta Idade Média na fronteira de Lafões: notas preliminares sobre a Arqueologia no Concelho de Vouzela

Manuel Luís Real / Catarina Tente

1641 Um conjunto cerâmico medieval fora de portas: um breve testemunho aveirense Susana Temudo

${ }_{1651}$ Os Lóios do Porto: uma perspetiva integrada no panorama funerário da Baixa Idade Média à Época Moderna em meios urbanos em Portugal

Ana Lema Seabra

1659 O Caminho Português Interior de Santiago como eixo viário na Idade Média Pedro Azevedo

1665 Morfologia Urbana: Um exercício em torno do Castelo de Ourém André Donas-Botto / Jaqueline Pereira

1677 Intervenção arqueológica na Rua Marquês de Pombal/Largo do Espírito Santo (Bucelas, Loures)

Florbela Estêvão / Nathalie Antunes-Ferreira / Dário Ramos Neves / Inês Lisboa

1691 O Cemitério Medieval do Poço do Borratém e a espacialidade funerária na cidade de Lisboa Inês Belém / Vanessa Filipe / Vasco Noronha Vieira / Sónia Ferro / Rodrigo Banha da Silva

1705 Um Espaço Funerário Conventual do séc. XV em Lisboa: o caso do Convento de São Domingos da Cidade Sérgio Pedroso / Sílvia Casimiro / Rodrigo Banha da Silva / Francisca Alves Cardoso

\section{9. Época Moderna e Contemporânea}

1721 Arqueologia Moderna em Portugal: algumas reflexões críticas em torno da quantificação de conjuntos cerâmicos e suas inferências históricas e antropológicas Rodrigo Banha da Silva / André Bargão / Sara da Cruz Ferreira

1733 Faianças de dois contextos entre os finais do século XVI e XVIII do Palácio dos Condes de Penafiel, Lisboa

Martim Lopes / Tomás Mesquita 
1747 Um perfil de consumo do século XVIII na foz do Tejo: O caso do Mercado da Ribeira, Lisboa Sara da Cruz Ferreira / Rodrigo Banha da Silva / André Bargão

1761 Os Cachimbos dos Séculos XVII e XVIII do Palácio Mesquitela e Convento dos Inglesinhos (Lisboa)

Inês Simão / Marina Pinto / João Pimenta / Sara da Cruz Ferreira / André Bargão / Rodrigo Banha da Silva

1775 "Tomar os fumos da erua que chamão em Portugal erua sancta». Estudo de Cachimbos provenientes da Rua do Terreiro do Trigo, Lisboa

Miguel Martins de Sousa / José Pedro Henriques / Vanessa Galiza Filipe

1787 Cachimbos de Barro Caulínitico da Sé da Cidade Velha (República de Cabo Verde)

Rodrigo Banha da Silva / João Pimenta / Clementino Amaro

1801 Algumas considerações sobre espólio não cerâmico recuperado no Largo de Jesus (Lisboa) Carlos Boavida

1815 Adereços de vidro, dos séculos XVI-XVIII, procedentes do antigo Convento de Santana de Lisboa (anéis, braceletes e contas)

Joana Gonçalves / Rosa Varela Gomes / Mário Varela Gomes

1837 Da ostentação, luxo e poder à simplicidade do uso quotidiano: arqueologia e simbologia de joias e adornos da Idade Moderna Portuguesa Jéssica Iglésias

1849 Os amuletos em Portugal - dos objetos às superstições: o coral vermelho Alexandra Vieira

1865 Cerâmicas de Vila Franca de Xira nos séculos XV e XVI Eva Pires

1879 «Não passa por teu o que me pertence». Marcas de individualização associadas a faianças do Convento de Nossa Senhora de Aracoeli, Alcácer do Sal Catarina Parreira / Íris Fragoso / Miguel Martins de Sousa

1891 Cerâmica de Leiria: alguns focos de produção

Jaqueline Pereira / André Donas-Botto

1901 Os Fornos na Rua da Biquinha, em Óbidos Hugo Silva / Filipe Oliveira

1909 A casa de Pêro Fernandes, contador dos contos de D. Manuel I: o sítio arqueológico da Silha do Alferes, Seixal (século XVI) Mariana Nunes Ferreira

1921 O Alto da Vigia (Sintra) e a vigilância e defesa da costa Alexandre Gonçalves / Sandra Santos

1937 O contexto da torre sineira da Igreja de Santa Maria de Loures Paulo Calaveira / Martim Lopes

1949 A Necrópole do Hospital Militar do Castelo de São Jorge e as práticas funerárias na Lisboa de Época Moderna Susana Henriques / Liliana Matias de Carvalho / Ana Amarante / Sofia N. Wasterlain

1963 SAND - Sarilhos Grandes Entre dois Mundos: o adro da Igreja e a Paleobiologia dos ossos humanos recuperados

Paula Alves Pereira / Roger Lee Jesus / Bruno M. Magalhães

1975 Expansão urbana da vila de Cascais no século XVII e XVIII: a intervenção arqueológica na Rua da Vitória no 15 a 17

Tiago Pereira / Vanessa Filipe

1987 Novos dados para o conhecimento do Urbanismo de Faro em época Moderna Ana Rosa 
1995 Um exemplo de Arqueologia Urbana em Alcoutim: o Antigo Edifício dos CTT Marco Fernandes / Marta Dias / Alexandra Gradim / Virgílio Lopes / Susana Gómez Martínez

2007 Palácio dos Ferrazes (Rua das Flores/Rua da Vitória, Porto): a cocheira de Domingos Oliveira Maia

Francisco Raimundo

2021 As muitas vidas de um edifício urbano: História, Arqueologia e Antropologia no antigo Recreatório Paroquial de Penafiel Helena Bernardo / Jorge Sampaio / Marta Borges

2035 O convento de Nossa Senhora da Esperança de Ponta Delgada: o contributo da arqueologia para o conhecimento de um monumento identitário João Gonçalves Araújo / N’Zinga Oliveira

2047 Arqueologia na ilha do Corvo... em busca da capela de Nossa Senhora do Rosário Tânia Manuel Casimiro / José Luís Neto / Luís Borges / Pedro Parreira

2059 Perdidos à vista da Costa. Trabalhos arqueológicos subaquáticos na Barra do Tejo Jorge Freire / José Bettencourt / Augusto Salgado

2071 Arqueologia marítima em Cabo Verde: enquadramento e primeiros resultados do projecto CONCHA

José Bettencourt / Adilson Dias / Carlos Lima / Christelle Chouzenoux / Cristóvão Fonseca / Dúnia Pereira / Gonçalo Lopes / Inês Coelho / Jaylson Monteiro / José Lima / Maria Eugénia Alves / Patrícia Carvalho / Tiago Silva

2085 Trabalhos arqueológicos na Cidade Velha (Ribeira Grande de Santiago, Cabo Verde): reflexões sobre um projecto de investigação e divulgação patrimonial André Teixeira / Jaylson Monteiro / Mariana Mateus / Nireide Tavares / Cristovão Fonseca / Gonçalo C. Lopes / Joana Bento Torres / Dúnia Pereira / André Bargão / Aurélie Mayer / Bruno Zélie / Carlos Lima / Christelle Chouzenoux / Inês Henriques / Inês Pinto Coelho / José Lima / Patrícia Carvalho / Tiago Silva

2103 A antiga fortificação de Quelba / Khor Kalba (E.A.U.). Resultados de quatro campanhas de escavações, problemáticas e perspectivas futuras Rui Carita / Rosa Varela Gomes / Mário Varela Gomes / Kamyar Kamyad

2123 Colónias para homens novos: arqueologia da colonização agrária fascista no noroeste ibérico Xurxo Ayán Vila / José Mạ . Señorán Martín 


\title{
CONTRIBUTO PARA O CONHECIMENTO DA COSMÉTICA ISLÂMICA, EM SILVES, DURANTE A IDADE MÉDIA
}

\author{
Rosa Varela Gomes ${ }^{1}$
}

\begin{abstract}
RESUMO
As numerosas escavações que temos dirigido de contextos islâmicos no sul de Portugal, designadamente em Silves, ofereceram, entre muito outro espólio, conjunto artefactual tipologicamente diversificado, que podemos relacionar com a cosmética. Entendemos esta como actividade que usa objectos e produtos destinados não só ao embelezamento, como à conservação e protecção do corpo, nomeadamente no caso dos humanos, da pele, cabelo, olhos, dentes, etc. . A cosmética tem existência próxima da medicina e, sobretudo, da farmácia. Palavras-chave: Silves, Cosmética, Aplicador de kohl, Pente, Pinça.
\end{abstract}

\begin{abstract}
The numerous excavations that we have conducted from Islamic contexts in the south of Portugal, particularly in Silves, offered, among many other items, a typologically diversified artefact set, which we can relate to cosmetics. We understand this as an activity that uses objects and products intended not only for beautifier, but also for the conservation and protection of the body, namely in the case of humans, skin, hair, eyes, teeth, etc. Cosmetics has a close existence to medicine and, especially, to the pharmacy.
\end{abstract}

Keywords: Silves, Cosmetics, Kohl pencils, Comb, Tweezers.

\section{INTRODUÇÃO}

O cuidado com o corpo, relacionado tanto com rituais religiosos (purificação dos crentes), como higiénicos e profilácticos, encontra-se presente em todo o mundo muçulmano medieval constando, também, na informação literária, dado constituir exigência tanto pessoal como colectiva, ligada à cidadania, religião e espiritualidade. Valorizava-se então a saúde e o bem-estar físico, conforme nos é transmitido, entre outros, pelo médico cirurgião Abū Merwān 'Abdal-Malik ibn Zuhr, mais conhecido por Avenzoar, que escreveu, no século XII, o primeiro livro sobre cosmética (Kitāb al-Iqtisād), com o objectivo de conservar, restaurar e, em particular, fazer ressaltar a beleza e perfeição criada por Deus; praticá-la é colaborar com o Criador (Brabant, 1974: 434; 1996: 298). Este aspecto que, de certo modo, questiona a exclusividade da criação Divina, poderá justificar a crítica dos teólogos almorávidas à obra daquele tratadista e a sua subsequente prisão. $\mathrm{O}$ mesmo texto refere tratamentos de embelezamento (tahsin) propondo, para tal, pomadas e unguentos, ou contra determinadas infecções da pele, pós para os dentes, colírios para os olhos e tintas para o cabelo ou a barba, além de produtos para dissimular cicatrizes, fortalecer o cabelo e as unhas, depilatórios, desodorizantes, perfumes e fumigações, recomendando mesmo a cirurgia estética, para corrigir a forma do nariz ou dos lábios (Brabant, 1974: 435; 1996: 289). Ibn Halsūn também se debruça, na centúria seguinte, sobre cosmética (tarīq al-zìna) no Livro dos Alimentos, encarando-a na perspectiva da farmacopeia (Gigandet, 1996).

Muito embora nas obras mencionadas tenhamos conhecimento de tratamentos para a conservação e protecção do corpo, existem poucas referências aos recipientes onde aqueles produtos eram guardados. Não obstante, sabe-se que as mulheres do al-Andalus conservavam o kohl, pigmento de cor negra para contornar os olhos, em frascos, que podiam ser de cerâmica, vidro ou metal, estes mais raros, e em pe-

1. Instituto de Arqueologia e Paleociências da Universidade Nova de Lisboa F.C.S.H.; rv.gomes@fcsh.unl.pt 
quenos estojos, enquanto as essências e óleos eram colocados e transportados em pequenos recipientes de vidro ou cristal (Arié, 1987: 300; Lévi-Provençal e Torres Balbás, 1982: 279).

Nas escavações arqueológicas que temos vindo a dirigir em Silves, há mais de três décadas, recolhemos conjunto artefactual que podemos relacionar com a cosmética. Este, encontrou-se, maioritariamente, na área palatina daquela cidade, onde residiria boa parte da sua elite e, sobretudo, nas zonas correspondentes aos complexos de banhos, do século XII ou dos inícios da centúria seguinte, tanto do palácio principal, como do localizado no lado nascente daquela Alcáçova (Gomes, 2003: 49-111, 188, 211; Gomes, 2015; Gomes e Gomes, 2001: 74-76). Também detectámos, exemplares descartados no interior de silos, usados como lixeiras, ou em fossa detrítica.

\section{ARTEFACTOS DE OSSO}

- Aplicador de kohl (Cast. Silv. Q32/C2-2). Fragmento que apresenta corpo de forma bitroncocónica alongada, possuindo a extremidade proximal arredondada, e a distal mostra elemento para encaixe em peça que teria orifício circular. Oferece decoração constituída por finas incisões, paralelas e perpendiculares ao seu eixo maior, organizadas em oito grupos. Mede o, 070 $\mathrm{m}$ de comprimento e o,oog $\mathrm{m}$ de maior diâmetro. Foi encontrado no pátio do complexo de banhos (hamman) do palácio principal, que terá pertencido ao governador da cidade (Gomes, 2003: 87, 187, 188) (Figura 1).

- Aplicador de kohl (Cast. Silv. Q537/C2-2). Fragmento que mostra corpo de forma bitroncocónica alongada, com a extremidade proximal piramidal, apresentando a distal elemento para encaixe em peça com orifício circular. A superfície exterior oferece decoração constituída por finas incisões, paralelas e perpendiculares ao seu eixo maior, organizadas em seis grupos. Mede o,043 $\mathrm{m}$ de comprimento e o,o1o $\mathrm{m}$ de maior diâmetro. Foi exumado no interior de uma das casas identificadas no sector noroeste do Castelo de Silves.

- Aplicador de kohl (Cast. Silv. Q301/Fos. 2-1). Fragmento que oferece corpo de forma bitroncocónica alongada, com a extremidade proximal piramidal, e a distal com elemento para encaixe em peça com orifício circular. A superfície exterior apresenta decoração constituída por finas incisões, paralelas e perpendiculares ao seu eixo maior, organizadas em seis grupos. Mede o,045 $\mathrm{m}$ de comprimento e o,006 $\mathrm{m}$ de maior diâmetro. Provém de fossa detrítica, reconhecida junto ao interior do pano de muralha do lado sudeste do Castelo de Silves.

- Pente (Cast. Silv. Q77/C2-1). Encontra-se reduzido a fragmento possuindo, apenas, quatro dentes e parte do corpo. Mede o,059 $\mathrm{m}$ de altu$\mathrm{ra}, \mathrm{o,010} \mathrm{m}$ de largura e 0,004 $\mathrm{m}$ de espessura máxima. Foi identificado em compartimento de casa localizada entre o pano de muralha do lado nascente e o palácio principal do Castelo de Silves (Gomes, 2003: 109, 188, 189).

- Pente duplo (Silv.4). Apresenta forma rectangular e possuía duas filas de dentes, uma contando actualmente, apenas, com seis dentes, espaçados, e, no lado oposto, vinte e três dentes, que seriam mais finos e juntos, mas agora reduzidos aos seus arranques. $O$ espaço entre as duas fiadas de dentes, é liso, mostrando apenas duas incisões junto aos dentes maiores. Mede o,053 $\mathrm{m}$ de altura, o,048 $\mathrm{m}$ de comprimento e o,oo6 m de espessura máxima. Foi achado na encosta situada no lado nascente do Castelo de Silves, juntamente com outro espólio islâmico proveniente, possivelmente, do interior daquele espaço (Gomes, 2003: 355; Gomes e Gomes, 2001: 74).

\section{ARTEFACTOS DE METAL}

- Pinça (Cast. Silv. Q108/C2-3). Produzida em liga de cobre, apresenta hastes de forma rectangular, contendo cada uma delas três linhas incisas na zona proximal. Mede o,046 m de comprimento e 0,004 $\mathrm{m}$ de largura. Foi exumada no complexo de banhos, junto a uma das tinas, do palácio principal da Alcáçova (Gomes, 2003: $87,188,190)$.

- Pinça (Cast. Silv. Q334/C2-1). Fabricada em liga de cobre, possui hastes de forma trapezoidal, oferecendo ambas, linhas incisas na zona distal. Mede 0,047 $\mathrm{m}$ de comprimento e o,008 $\mathrm{m}$ de largura máxima. Foi descoberta junto a uma das casas existentes no sector noroeste do Castelo de Silves. 


\section{ARTEFACTOS DE VIDRO}

- Taça (Cast. Silv. Q74/C2-8). Quase completa, mostra corpo troncocónico, bordo oblíquo, possuindo lábio de secção semicircular e assenta em fundo côncavo. Foi fabricada com vidro, translúcido, de cor azul. Mede o,064 $\mathrm{m}$ de diâmetro no bordo, o,032 $\mathrm{m}$ de diâmetro no fundo, 0,030 $\mathrm{m}$ de altura e a espessura média das paredes é de $\mathrm{0}, 002 \mathrm{~m}$. Foi recolhida junto de frasco, no interior de canalização situada a norte do complexo de banhos do palácio principal da Alcáçova de Silves (Cast. Silv. Q74/C2-7) (Gomes, 2003: 104, 208, 211; Gomes, 2015:442; Gomese Gomes, 2001: 75).

- Taça hemisférica achatada (Cast. Silv. Q20/C2-7). Fragmento contendo porção do bordo e do corpo. Mostrava corpo de forma hemisférica achatada, com bordo vertical, espessado no exterior, com lábio de secção semicircular. Foi fabricada com vidro, opaco, de cor verde água. Media o,080 m de diâmetro no bordo e a espessura média das paredes é de o,002 $\mathrm{m}$. Provém do pátio anexo ao complexo de banhos do palácio principal (Gomes, 2003: 94, 208, 211; Gomes, 2015: 442).

- Frasco (Cast. Silv. Q74/C2-7). Conserva-se inteiro. Mostra corpo de forma esférica, algo achatada e gargalo alto, troncocónico. O bordo, ligeiramente espessado, apresenta lábio de secção semicircular. O fundo contém ônfalo. O corpo oferece decoração, constituída por pequenos motivos ovais em relevo. Foi fabricado com vidro, translúcido, de cor castanha esverdeada. Mede $0,130 \mathrm{~m}$ de altura, 0,026 $\mathrm{m}$ de diâmetro no bordo, o, $028 \mathrm{~m}$ de diâmetro na base e a espessura média das paredes é de $0,002 \mathrm{~m}$. Este raro exemplar deve ter sido utilizado para conter perfume. Foi recuperado, com outras peças sumptuárias, no interior de canalização situada a norte do complexo de banhos do palácio principal, ali escondido aquando do fim da administração muçulmana (Gomes, 2003: 104, 209, 211; Gomes, 2015: 442; Gomes e Gomes, 2001: 76).

- Frasco (Cast. Silv.Q35/C2-7). Mostrava corpo de forma esférica achatada, possuía gargalo alto, troncocónico. Conserva-se fragmento contendo porção do bordo, gargalo, com o arranque de duas asas e parte do corpo. O bordo é vertical, afilado e apresentava lábio de secção semicircular. Possivelmente, assentava em fundo com pé anelar, dados os paralelos com outras peças. As extremidades superiores das asas estavam fixadas a meio do gargalo e as inferiores repousavam a meio do volume do corpo. Foi fabricado com vidro, opaco, de cor castanha avermelhada. Mede o,046 m de diâmetro no bordo, o,070 m de diâmetro no corpo e a espessura média das paredes é de $0,002 \mathrm{~m}$. Encontrava-se sobre o pavimento de corredor de acesso a instalação sanitária, de apoio ao complexo de banhos do palácio principal (Gomes, 2003: 91, 209, 211; Gomes, 2015: 442).

- Frasco (Cast. Silv. Silo 4 - 94). Fragmentos correspondentes ao bordo, ao corpo e ao fundo. $\mathrm{O}$ corpo possuía forma ovoide e assentava em pé baixo e anelar. O bordo era ligeiramente espessado e algo extrovertido, com lábio em bisel. Foi fabricado com vidro, translúcido, de cor verde. Oferece, no corpo, decoração moldada, com motivos ovais e circulares, em relevo, junto ao fundo. Mede o,094 $\mathrm{m}$ de diâmetro no bordo, 0,029 $m$ de diâmetro no fundo e a espessura média das paredes é de $0,002 \mathrm{~m}$. O silo que o continha situa-se na zona norte da Alcáçova de Silves.

- Frasco (Cast. Silv. Silo 4 - 96). Fragmentos correspondendo a parte do gargalo e do fundo. Apresenta corpo de forma troncocónica, assente em fundo côncavo. O gargalo troncocónico era alto e largo. O bordo, ligeiramente introvertido, possuía lábio de secção semicircular. Foi fabricado com vidro, translúcido, de cor verde. Mede 0,054 m de diâmetro no bordo, 0,045 m de diâmetro no fundo e a espessura média das paredes é de o,002 m. Foi encontrado próximo da peça anteriormente descrita.

- Pequenos frascos (alabastra) (Cast. Silv. Q282/ C2-2; Cast. Silv. Q.282/C2-1; Cast. Silv. 284/C21). Quase completos, mostram corpo fusiforme, gargalo alto e troncocónico, com anel na ligação com o corpo. O bordo, espessado e extrovertido, apresenta lábio de secção semicircular. Os fundos são planos. Possuíam pequenas tampas, também de vidro, que encaixavam em estrangulamento do bordo. Foram produzidos com vidro marmoreado, opaco, de cor vermelha vinhosa e oferecem decoração de reflexos metálicos dourados. Medem entre $0,079 \mathrm{~m}$ e $0,082 \mathrm{~m}$ de altura, o,016 $\mathrm{m}$ a 0,019 $\mathrm{m}$ de diâmetro no bordo e o,008 $\mathrm{m}$ a o,010 $\mathrm{m}$ de diâmetro no fundo. Foram recolhidos, com muitos outros fragmentos 
de recipientes congéneres, no interior de compartimento anexo ao complexo de banhos do palácio, que se desenvolvia paralelamente ao pano interior da muralha nascente do Castelo de Silves (Gomes, 2015:442, 444; Gomes, 2016: 23; Gomes e Gomes, 2001: 75).

\section{ARTEFACTOS DE CERÂMICA}

- Pote (Cast. Silv. Q144/C2-1). Quase completo, dado apenas faltarem-lhe alguns fragmentos do corpo e as asas. Mostra corpo de forma ovoide, bordo baixo algo introvertido, possuindo lábio de secção recta. Assenta em pé anelar destacado e teria duas pequenas asas, opostas, de que subsistem os arranques. Foi fabricado com pasta, homogénea e compacta, de cor cinzenta clara $\left(5 \mathrm{Y}_{7} / 1\right)^{2}$ contendo elementos, não plásticos, de grão finíssimo a fino. A superfície interior mostra cor semelhante à do núcleo, enquanto a exterior apresenta esmalte, aderente mas sem brilho, de cor verde. Esta oferece várias linhas, incisas, dispostas horizontalmente. Mede o,077 m de altura, o,037 m de diâmetro no bordo, o,040 m de diâmetro no pé e a espessura média das paredes é de $0,005 \mathrm{~m}$. A forma do bordo indica que teria tampa. Foi recolhido no pátio do palácio principal do Castelo de Silves (Gomes, 2003: 240, 241) (Figura 2).

- Frasco (balsamário) (Cast. Silv. Q268/C2-1). Fragmento correspondendo ao corpo, com forma ovoide, ao gargalo e ao bordo. O gargalo é estreito e o bordo ligeiramente extrovertido, mostrando lábio com secção semicircular. Foi fabricado com pasta, homogénea e compacta, de cor branca (10 YR 8/2), contendo elementos, não plásticos, de grão finíssimo a fino. Ambas superfícies apresentam cor semelhante à do núcleo, oferecendo a exterior, na zona mesial, decoração constituída por caneluras horizontais. Conserva parte da tampa, de chumbo, no interior do bordo, presa por arame de cobre. Mede 0,020 $\mathrm{m}$ de diâmetro no bordo e a espessura média das paredes é de o,002 $\mathrm{m}$. Foi recolhido no depósito de água que abastecia complexo de banhos do palácio, que se desenvolvia paralelamente ao pano interior da muralha nascente do

2. Os códigos cromáticos correspondem às Munsell Soil Color Charts e, por isso, devem considerar-se como aproximados.
Castelo de Silves (Gomes, 2003: 75, 293, 297; Gomes e Gomes, 2001: 92).

- Frasco (balsamário) (Cast. Silv. Q51/C3-1). Quase completo, mostra corpo globular, gargalo estreito, com bordo vertical, possuindo lábio de secção semicircular. Assenta em fundo destacado, mas plano. Foi fabricado com pasta, homogénea e compacta, de cor branca (10 YR 8/2), contendo elementos, não plásticos, de grão fino. Ambas superfícies possuem cor igual à da pasta. A superfície exterior oferece decoração, formada por caneluras horizontais que preenchem a sua zona mesial. Mede $0,074 \mathrm{~m}$ de altura, 0,008 $\mathrm{m}$ de diâmetro no bordo, 0,034 $\mathrm{m}$ de diâmetro no fundo e a espessura média das paredes é de o,003 $\mathrm{m}$. Foi recolhido sob o pavimento do compartimento 1 da casa B, do Castelo de Silves (Gomes e Gomes, 2001: 61; Gomes, 2003: 109, $346,383,384)$.

- Frasco (balsamário) (Cast. Silv. Silo 6-8). Fragmento correspondendo ao gargalo, ao corpo, de forma ovoide alongada, e ao fundo. O gargalo é cilíndrico e baixo, possuindo bordo introvertido com lábio em bisel. O fundo era ligeiramente convexo. Foi fabricado com pasta, homogénea e compacta, cor-de-laranja (5 YR 6/8), contendo elementos, não plásticos, de grão fino a médio. Ambas superfícies apresentam cor semelhante à da pasta. Observa-se, na superfície exterior, decoração constituída por várias caneluras paralelas que preenchem a superfície mesial. Mede o,176 m de altura, o,o26 $\mathrm{m}$ de diâmetro no bordo, o,024 $\mathrm{m}$ de diâmetro no fundo e a espessura média das paredes é de o,004 m. O silo de onde provém situa-se na zona norte da Alcáçova de Silves.

- Frasco (balsamário) (AR. Q1/E3/C1-3o). Quase completo. Apresenta corpo de forma globular, assentando em pé, destacado e em bolacha. Mostra gargalo baixo, com bordo provido de lábio de secção semicircular. Foi fabricado com pasta, homogénea e compacta, de cor rosada (5 YR 7/4), contendo elementos, não plásticos, de grão finíssimo e, alguns, de grão médio. A superfície interior oferece cor algo mais escura que a da pasta, enquanto à exterior foi aplicada aguada de cor branca. Possui, na superfície do volume mesial, decoração constituída por várias caneluras horizontais. Mede $0,113 \mathrm{~m}$ de altura, 0,026 $\mathrm{m}$ de diâmetro no bordo, o,047 m 
de diâmetro no pé e a espessura média das paredes é de o,o03 $\mathrm{m}$. Provém do interior de silo, da designada Zona da Arrochela, na área urbana de Silves (Gomes, 2011: 92, 104, 124, 125).

\section{COMENTÁRIO}

Entre os artefactos de osso inventariados, os aplicadores de kohl ou "kohl pencils" apresentam a extremidade proximal mais espessa e de forma bitroncocónica, indicando a pega. A todos falta a extremidade distal, ao que parece móvel. Exemplares completos, com as mesmas funções, produziram-se em distintas matérias-primas como metal, vidro, madeira, marfim, osso e pedra, possuindo a maioria cerca de o,10 m de comprimento. A descoberta de aplicadores de kohl, fabricados em vidro, durante os trabalhos arqueológicos que, nos últimos anos, temos vindo a realizar na antiga fortaleza de Quelba/Khor Kalba, no Emirado de Sharjah (EAU), conduziu-nos a obter mais informação sobre aqueles artefactos de cosmética, tanto a partir dos exemplares patentes em Museus, como em colecções particulares ou na bibliografia arqueológica e etnográfica (Gomes, 2019: 132, 133).

O kohl (marwad/mirwed), fabricado com sulfitos de antimónio e de chumbo, pulverizados, ou negro de fumo, de girassóis e essências vegetais queimadas, reduzidas a pó, podia ser misturado com óleos $(\mathrm{ka}-$ jal), sendo usado desde o III milénio A.C., e ainda hoje, por mulheres, homens e crianças em todo o mundo islâmico, de Marrocos à Índia, no contorno dos olhos, sobre as pálpebras e até nas sobrancelhas. Ele tem funções estéticas e sobretudo profiláticas, protegendo a vista de infecções, provocadas pela poeira, ou dos raios solares, mas, igualmente, apotropaicas em particular contra o mau olhado. No al-Andalus as mulheres utilizaram $k o h l$, tanto nas sobrancelhas como nas pestanas (Arié, 1987: 300). Este produto, nos finais dos anos sessenta do século passado, era vendido nos souks marroquinos, em pequenos frascos de vidro de uso farmacêutico, ainda com as tampas originais de borracha, associando-o de certo modo, aos medicamentos. O aplicador de kohl, vendido separadamente, oferecia duas extremidades, rematadas por pontas arredondadas, sendo uma, a distal, de menor dimensão que a oposta, permitindo realizar traço mais fino (Figura 3A). No Museu de Arqueologia do Emirado da Fujairah (EAU), observa-se exemplar semelhante, atribuído aos inícios do século passado (Figura 3 B). Na Península Arábica as elites guardavam o kohl em recipientes de vidro e sobretudo de prata, cujo aplicador, no mesmo material, se encontrava preso àquele por pequena corrente, conforme se observa em peças, do século XIX, iemenitas, possuindo corpo cilíndrico ou fusiforme (Figura 4).

Os pequenos recipientes fusiformes de vidro, dos quais descrevemos três exemplares, encontrados quase completos, mas de que exumámos abundantes fragmentos, correspondendo a gargalos e fundos, foram utilizados para conter perfumes ou mais provavelmente kohl, pois muitos dos fragmentos ainda conservavam restos daquele cosmético de cor negra. Confirma a nossa interpretação, a identificação em escavações arqueológicas, realizadas em Israel, nos sítios de Khirbet el-Minyeh, Tel Erani e al-Tūr, de pequenos frascos de perfumes e de outros de forma idêntica aos de Silves, contendo ainda kohl, com cronologias situadas entre os séculos VIII e o XV (Brosh, 1993: 290-292). Naquele último arqueossítio, importante porto e centro produtor de vidro, foi encontrado pequeno recipiente e respectivo aplicador de kohl, produzido em cobre (Shindo, 1993: 303, 304). Ao longo da costa do Mar Vermelho têm sido descobertos frascos de vidro para kohl, com decoração marmoreada, atribuídos a período compreendido entre os séculos VII-VIII e XIII (Shindo, 1993: 303).

Pequenos contentores para kohl, de vidro, figuram em diversas colecções, entre outras, nas do Museu do Louvre, em Paris, ou no Corning Museum of Glass de Nova York (Pasquier, 2007: 42, 83).

Os pentes, de osso, oferecem forma rectangular, podendo ter uma ou duas fiadas de dentes. Estes possuem dentes mais espaçados e de maiores dimensões em um dos lados, enquanto do oposto aqueles são menores e mais numerosos. Eram utilizados, tal como hoje, no tratamento do cabelo, ordenando-o ou penteando-o, e na sua higiene, dado poderem remover parasitas, embora, não raro, constituíssem adornos, interpretados como itens de riqueza, quando produzidos em matérias primas raras ou preciosas, como o marfim, prata ou ouro, e possuíssem decorações de dimensão simbólica. No mundo islâmico os pentes, "com numerosos dentes" eram usados para desembaraçar o cabelo e, em particular, ajudar a alterar a sua cor, aplicando henna, preferencialmente no hamman, usando o compartimento correspondente aos banhos temperados (bayt al-sajun) mas, apenas, 
uma vez por estação (Aguirre de Cárcer, 1995: 229; Gigandet, 1996: 51, 82).

A henna, embora fosse utilizada na cosmética, possui, segundo Ibn Halsūn, maravilhosas propriedades, sendo indicada para prevenir aftas, fortalecer o cabelo e as unhas, embelezando-as e, misturada com outros ingredientes, para fazer sabão (Gigandet, 1996: 53, 58, 65). No al-Andalus as mulheres alisavam o cabelo com pentes de osso ou marfim e decoravam as unhas com henna (Arié, 1987: 300). Presentemente, as mulheres muçulmanas, tanto do Norte de África como do Próximo e Médio Oriente, utilizam-na para decorar as mãos e os pés, prática que quiçá se deve a influência indiana, existindo especialistas na sua aplicação, que executam elaborados e esteticamente apelativos motivos decorativos. A henna era considerada uma planta abençoada, com grande baraka que, segundo parece, o Profeta tinha-a em conta como "A rainha de todas as flores", cujo perfume se associa ao Paraíso (Chebel, 2001: 197). A utilização da henna teria, por isso, carácter profiláctico e apotropaico.

Muito embora o cabelo devesse estar bem tratado, na mitologia muçulmana é considerado como sendo a ligação entre as forças do bem e as do mal devendo, por isso, ser protegido, conforme fazem as mulheres escondendo-o sobre lenços ou os homens ao cobrirem a cabeça com cafias sobre toucas de algodão (Chebel, 2001: 95). Deste modo, ambos se protegem não só de encantamentos como de, possíveis, forças demoníacas.

Pequenas pinças, de liga de cobre, seriam, de igual modo, utilizadas, por ambos géneros na depilação facial ou corporal. Esta podia ocorrer no ambiente doméstico, conforme indicam as duas pinças anteriormente referidas, ou no hamman, onde além de depiladoras profissionais existiam massagistas e cabeleireiras, que vendiam unguentos, perfumes e saquinhos de pós aromáticos para os vestidos (Lévi-Provençal e Torres Balbás, 1982: 279; Marín, 200o: 234, 235). O género de tais profissionais dependia do dos utilizadores daquele espaço. No seu desempenho as cabeleireiras e massagistas também se deslocavam a casa de mulheres com elevado estatuto social (Marín, 2000: 287, 297).

Os frascos, de vidro, apresentam corpo de forma esférica, esférica achatada, por vezes com altos gargalos, ovoide ou fusiforme, constituindo pequenos contentores de perfumes ('athan) ou de unguentos. As taças conteriam pomadas e outros preparados cosméticos. Teriam as mesmas funções exemplares de cerâmica, pequenos potes e frascos, que oferecem corpo de forma globular ou ovoide.

A maior parte das peças, de vidro ou de cerâmica, que exumámos na Alcáçova de Silves foi encontrada, conforme mencionámos anteriormente, junto ou próximo aos complexos de banhos.

Perfumes e unguentos eram, em todo o mundo islâmico, muito apreciados, relacionando-se com a socialização e a saúde. Produtos de cosmética, como os óleos, de amêndoas doces ou de rosas, eram então usados depois dos banhos, não só para hidratar a pele como para perfumar o corpo. Recomendava-se, entre outros, o óleo de jasmim para tornar a pele do rosto macia, enquanto, no corpo o óleo a aplicar dependia da estação do ano (Gigandet, 1996: 65, 66). A utilização de essências e unguentos estava interdita, segundo interpretação do Corão, durante a Peregrinação a Meca (Alcorão, Cap. 2, Ver. 157).

Os perfumes, considerados substâncias benignas, eram usados tanto na liturgia como no quotidiano, através de fumigações ou da cosmética, sendo os de melhor qualidade fabricados no Omã e no Iémen, onde se produzia o incenso e a mirra, sendo comercializados, através do Egipto ou do Golfo Arábico, para diferentes destinos (Chebel, 2001: 326, 327). A venda destas essências constituía importante actividade que terá estado associada ao nome de uma das portas situada no arrabalde ocidental de Córdova, designada por Bāb Al-'Attārīn, a porta dos vendedores de perfumes, sendo muito frequentada, em particular, por público feminino (Alesa, 2007: 225; Marín, 200o: 235, 304).

As essências eram produzidas com várias matérias-primas, dispendiosas como a algalia, e outras substâncias que incluem o âmbar cinzento, sândalo, açafrão, noz de moscada, canela, gordura de camelo, óleos vegetais e estratos florais ou cítricos, entre outros (Brabant, 1996: 297). A importância das essências conduziu a que, conforme relatámos, se tivesse escondido frascos de vidro, cujo conteúdo seria considerado precioso, numa canalização do Castelo de Silves.

Os vidros produzidos tanto no Sharq al-Andalus como no Próximo Oriente seriam peças dispendiosas, mas a cujo valor se associava o do seu conteúdo, as essências raras e os perfumes exóticos, vindos de longe. Eles confirmam o relacionamento comercial a longa distância e indicam a presença, no Castelo de Silves, de estrato social com usos e costumes orien- 
tais, poder económico e gosto requintado para utilizar, no seu quotidiano, peças e produtos raros, exógenos e dispendiosos. O comércio mediterrânico de recipientes de vidro e dos seus conteúdos, encontra-se documentado, em Silves, através dos exemplares descritos e de muitos outros, que eram vendidos em diferentes destinos, conforme bem documenta barco afundado no porto de Bodrum, em Seçe Limani (Turquia), com vidros fatímidas (Pasquier, 2007: 43). De facto, a circulação de pessoas, bens e ideias, durante a Idade Média (séculos VIII-XIII), entre o Ocidente Peninsular e o Mediterrâneo Oriental, em viagens de carácter religioso ou comercial, encontra-se assinalada em distinta informação literária e é, também, confirmada através dos espólios que temos vindo a encontrar nas escavações arqueológicas de Silves (cerâmicas, vidros, metais, elementos arquitectónicos, jóias...), ao longo de diferentes ocupações, nomeadamente da sua Alcáçova, abrangendo período compreendido entre 713 e 1248.

\section{BIBLIOGRAFIA}

ALCORÃO (2002) - Complexo do Rei Fahd, Medina, Arábia Saudita, Mem Martins: Sporpress.

AGUIRRE DE CÁRCER, Luisa Fernanda, (1995) - Ibn Wāfid (m.46o/1067), Kitāb Al-Adwiya Al-Mufrada (Libro de los Medicamentos Simples), vol. I. Madrid: Consejo Superior de Investigaciones Científicas / Agencia Española de Cooperatión Internacional.

ALESA, Muhammad Sayyah Mesned (2007) - El Estatus de la Mujer en la Sociedad Árabo-Islámica Medieval Entre Oriente y Ocidente. Granada: Universidad de Granada.

ARIÉ, Rachel (1987) - España Musulmana (Siglos VIII-XV), Barcelona: Edición Labor.

BRABANT, Rosa Kühne (1974) - Avenzoar y la cosmética, Orientalia Hispanica, vol. I, pp. 428-437.

BRABANT, Rosa Kühne (1996) - Zīna e Islāh. Reflexiones para entender la medicina estética del joven Abū Marwān b. Zuhr (ob. 1161/2), Al-Andalus-Magreb, ํํ4, pp. 281-298.

BROSH, Na'ama (1993) - Kohl bottles from Islamic periods excavated in Israel, Annales du $12^{e}$ Congrès de l'Association Internationale pour L'Histoire du Verre, pp. 289-295. Amsterdam: Association Internationale pour L'Histoire du Verre.

CHEBEL, Malek (2001) - Dictionnaire des Symboles Musulmans. Paris: Éditions Albin Michel.

GOMES, Mário Varela (2019) - Aplicador de kohl / Kohl applicator / Appliqueur de kohl, Identidade e Cultura. Património Arqueológico de Sharjah (EAU), pp. 132, 133. Lisboa: Museu Nacional de Arqueologia / Sharjah Archaeological
Autority / Instituto de Arqueologia e Paleociências da Universidade NOVA de Lisboa.

GOMES, Rosa Varela (2003) - Silves (Xelb) - Uma Cidade do Gharb al-Andalus. A Alcáçova. Trabalhos de Arqueologia, $\mathrm{n}^{\circ}$ 35. Lisboa: Instituto Português de Arqueologia.

GOMES, Rosa Varela (2011) - Silves (Xelb) - Uma Cidade do Gharb al-Andalus. A Zona da Arrochela. O Espaço e o Quotidiano. Trabalhos de Arqueologia, $\mathrm{n}^{\circ}$ 53. Lisboa: Instituto de Gestão do Património Arquitectónico e Arqueológico.

GOMES, Rosa Varela (2015) - Islamic Glass from Silves' Castle (Portugal), Annales du $19^{e}$ Congrès de l'Association Internationale pour l'Histoire du Verre (Piran, 2012), pp. 438-445. Koper: Association Internationale pour l'Histoire du Verre.

GOMES, Rosa Varela (2016) - Antecedentes da construção naval em Portugal, A Gestão dos Recursos Florestais Portugueses na Construção Naval da Idade Moderna: História e Arqueologia, pp. 23-32. Lisboa: Instituto de Arqueologia e Paleociências da Universidade Nova de Lisboa.

GOMES, Rosa Varela; GOMES, Mário Varela (2001) - Palácio Almoada da Alcáçova de Silves. Lisboa: Museu Nacional de Arqueologia.

LÉVI-PROVENÇAL, Évariste; TORRES BALBÁS, Leopoldo (1982)-España Musulmana (711-1031), Instituciones, sociedad, cultura, História de España, tomo V. Madrid: Espasa-Calpe.

GIGANDET, Suzanne (1996) - Ibn Halsūn, Le Livre des Aliments (KITĀB Al-AǴDIYA), Santé et diététique chez les Arabes au XIII siècle. Damas: Institut Français de Damas.

MARÍN, Manuela (200o) - Mujeres en Al-Ándalus. Madrid: Consejo Superior de Investigaciones Científicas.

PASQUIER, Jacqueline du (2007) - Histoire du Verre les Chefs-D’Oeuvre de L'Islam. Paris: Massin Éditeur.

SHINDO, Yoko (1993) - Islamic marvered glass from al-Tūr, South Sinai, Annales du $12^{e}$ Congrès de l'Association Internationale pour L'Histoire du Verre, pp. 297-305. Amsterdam: Association Internationale pour L'Histoire du Verre. 

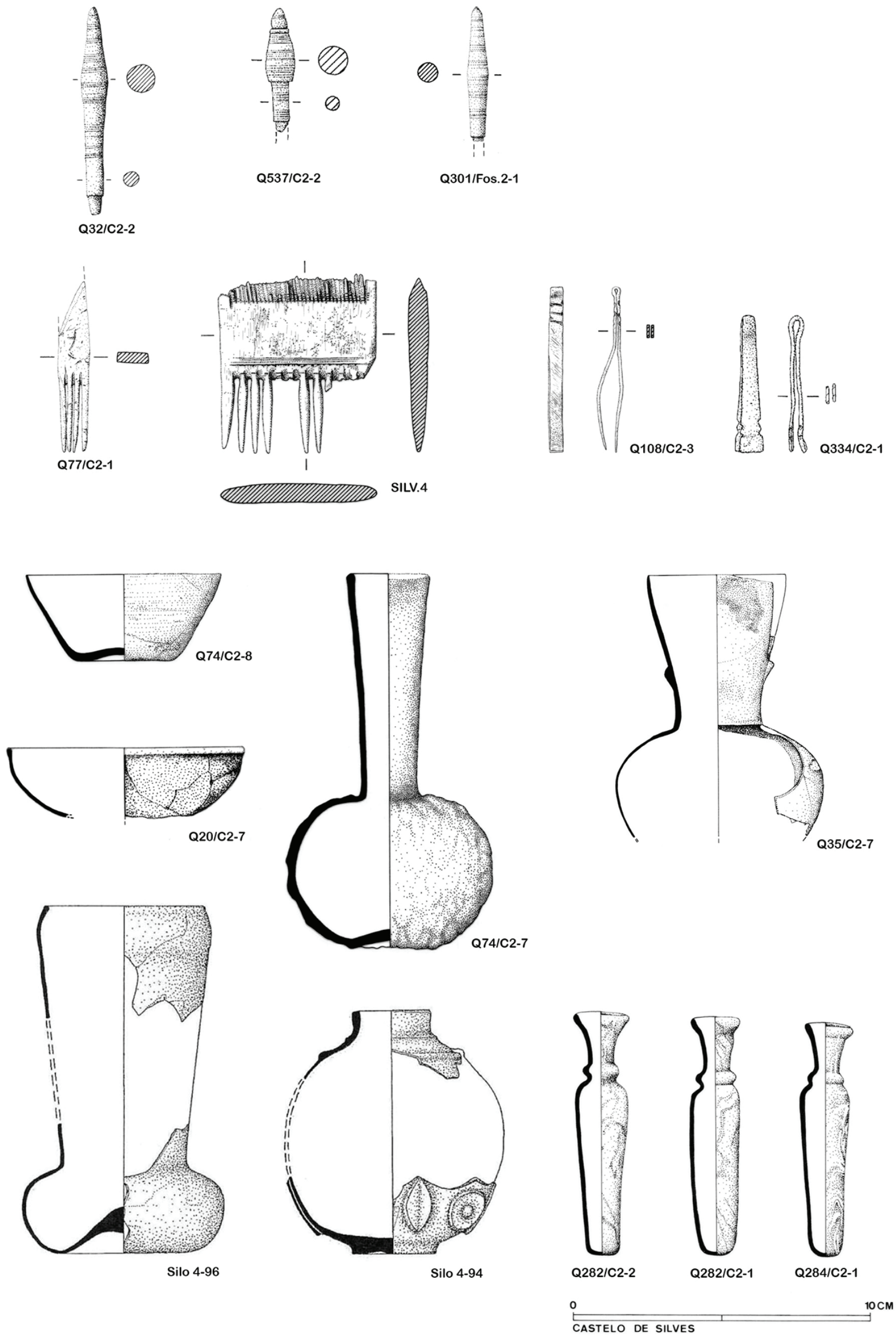

Figura 1 - Artefactos de cosmética, de osso, metal ou vidro. Silves (des. A. Machado; J. Gonçalves; S. Costa). 

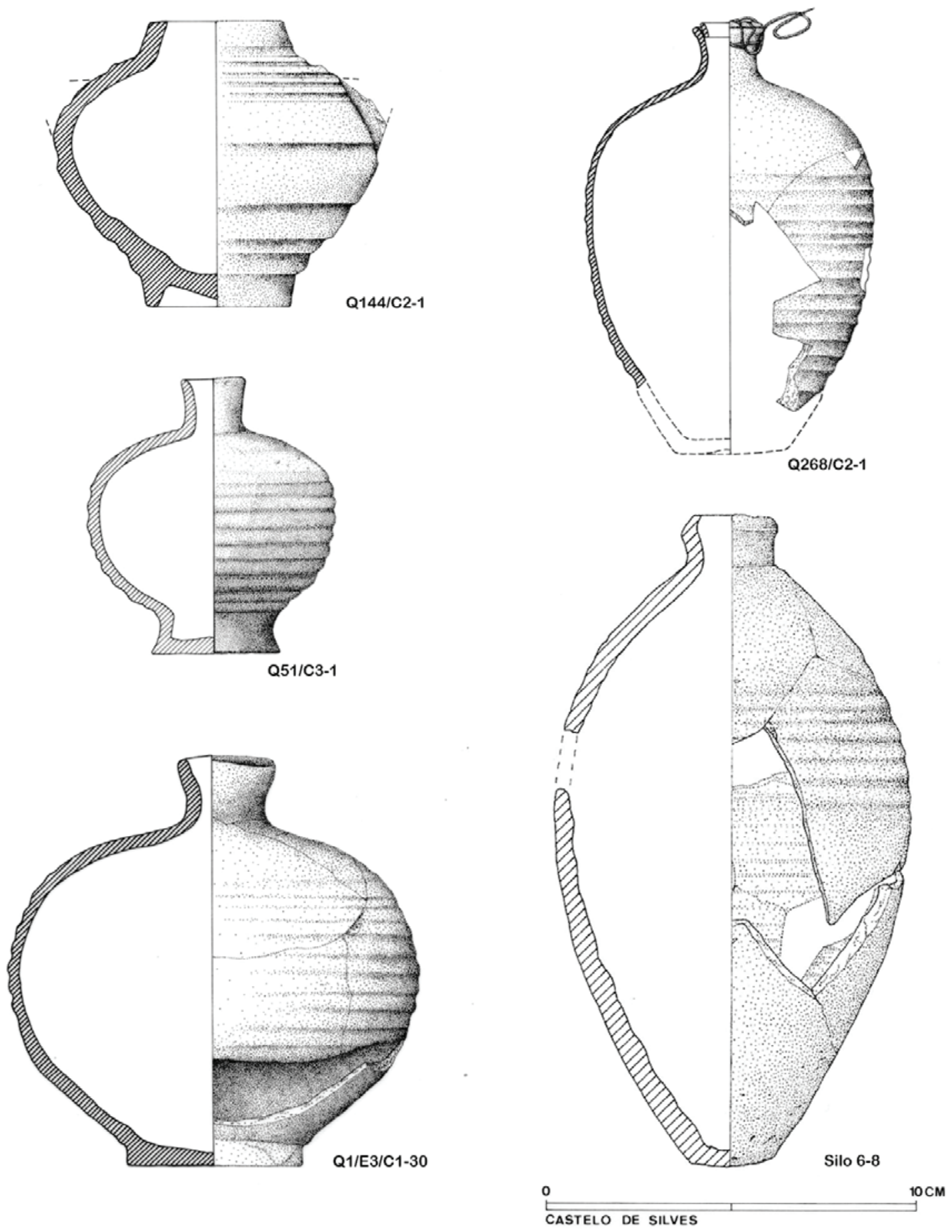

Figura 2 - Artefactos, de cerâmica, ligados à cosmética. Silves (des. A. Machado; C. Gaspar; S. Costa). 

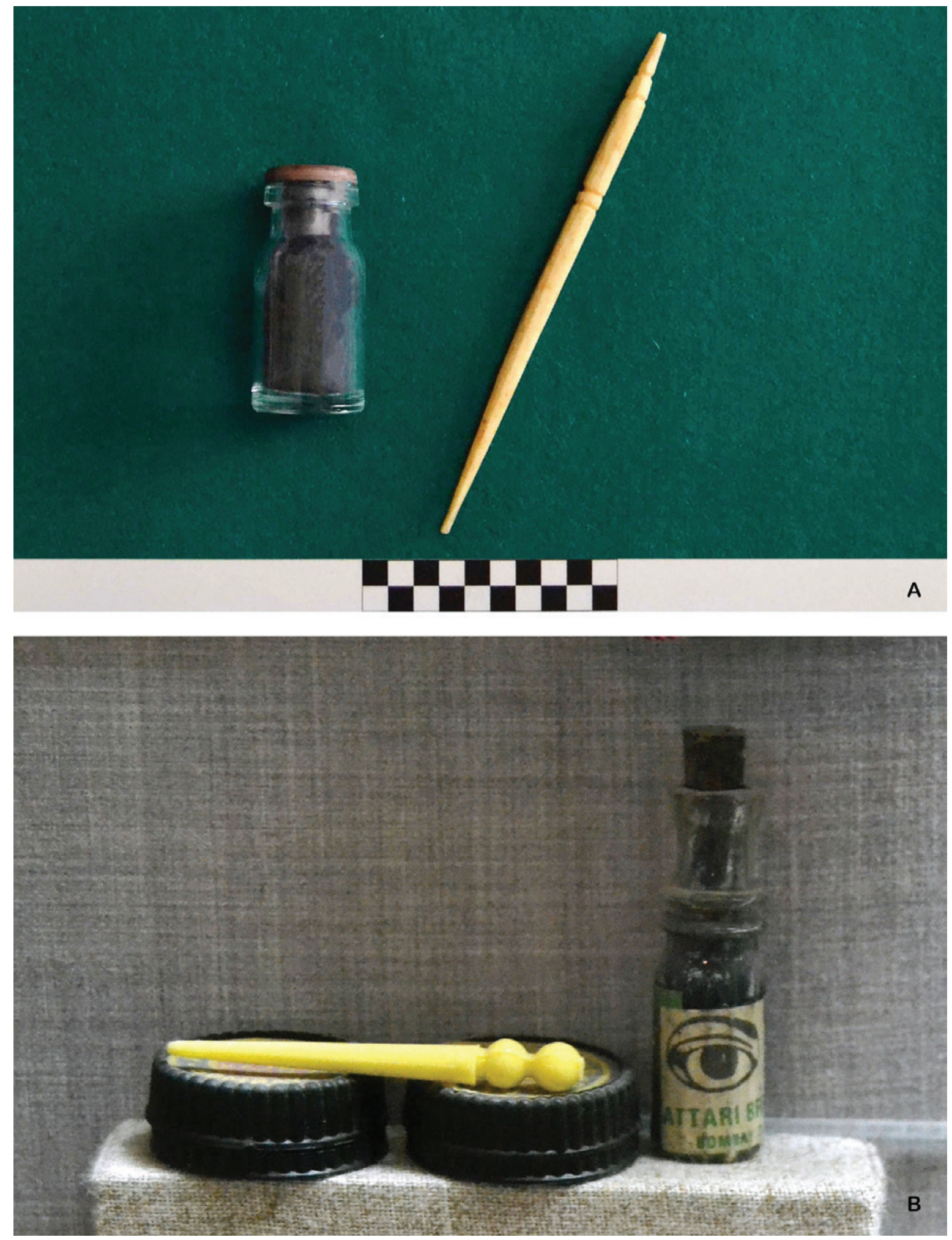

Figura 3 - A - Frasco de vidro, com tampa de borracha, contendo kohl, e aplicador de osso. Marrocos, finais dos anos sessenta da passada centúria (col. R. e M. Varela Gomes). B - Frasco de vidro contendo kohl e aplicador, em exibição no Museu de Arqueologia do Emirado da Fujairah (EAU) (fotos Rita Varela Gomes). 


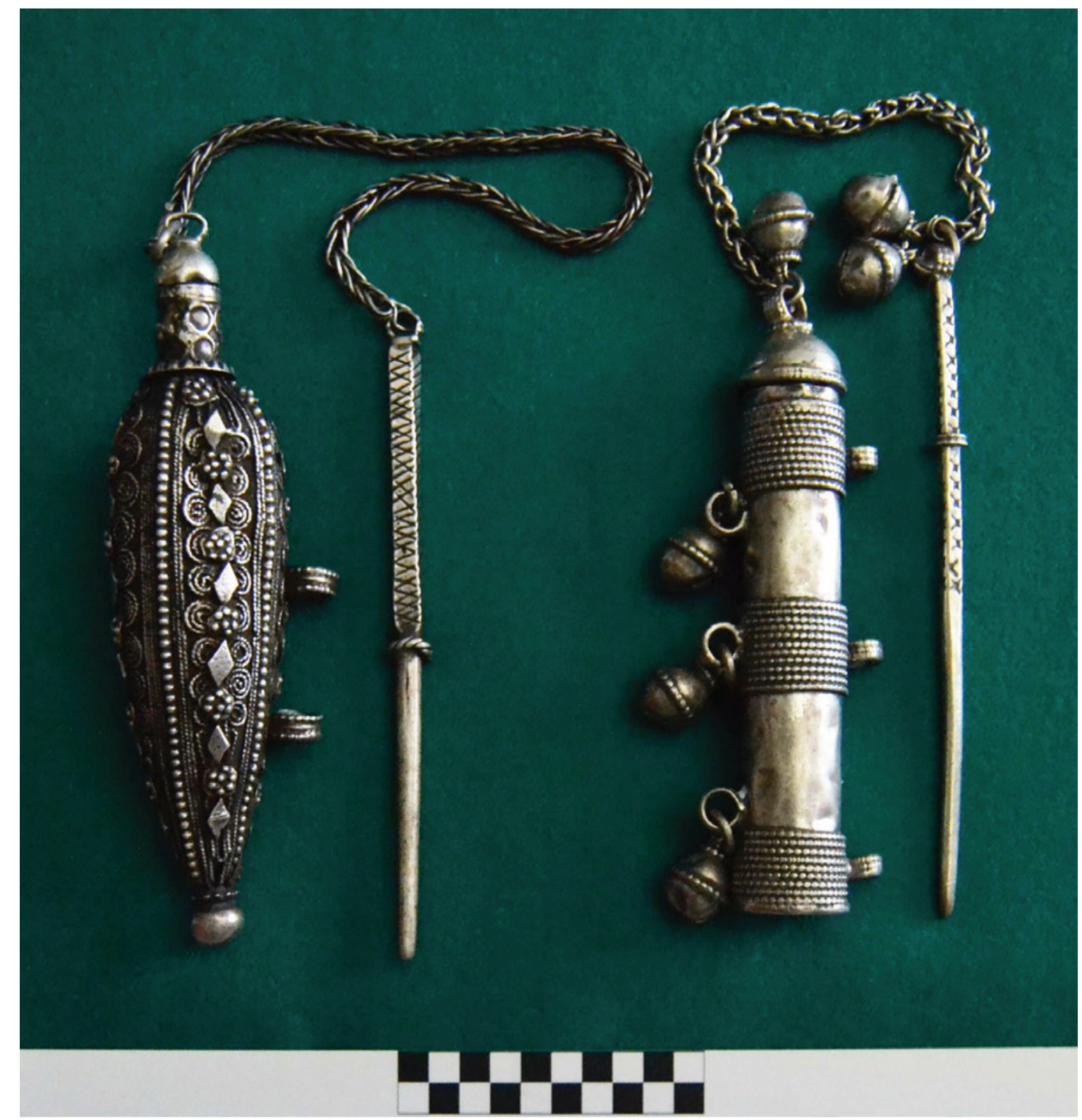

Figura 4 - Recipientes iemenitas para kohl e respectivos aplicadores, de prata, do século XIX (col. R. e M. Varela Gomes) (foto Rita Varela Gomes). 


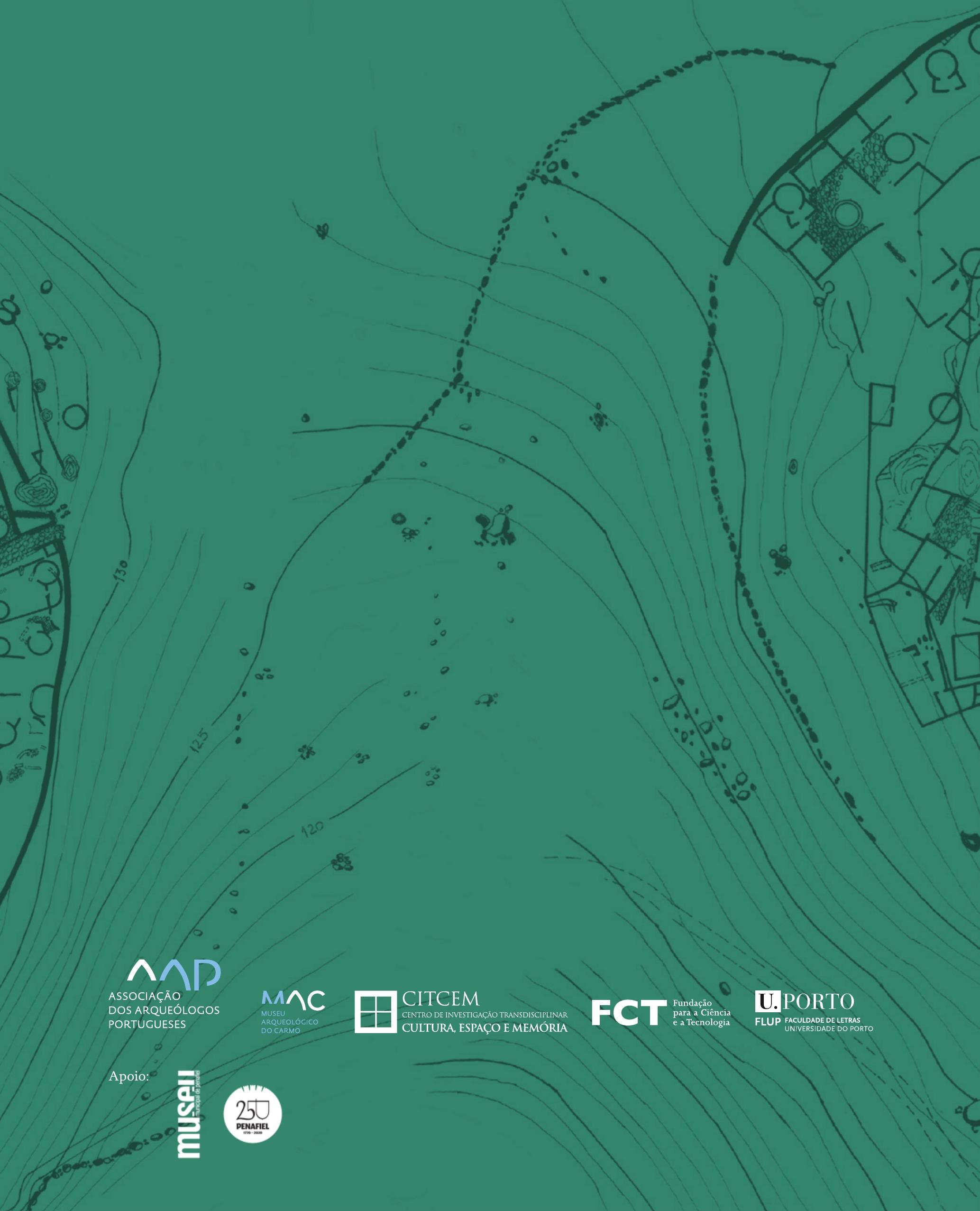

